\title{
PENGARUH KETERLIBATAN KERJA TERHADAP KINERJA PEGAWAI DENGAN MEDIASI KOMITMEN ORGANISASI PADA BEBERAPA KANTOR DINAS DI KOTA BENGKULU
}

\author{
Paryati \\ Praningrum \\ Sugeng Susetyo \\ Jurusan Manajemen, Fakultas Ekonomi dan Bisnis, Universitas Bengkulu
}

\begin{abstract}
The purpose of this study is examined the effect of job involvement on employees performance mediated with organizational commitment at some service office of Bengkulu city. This research was conducted at some service office of Bengkulu City. The object of research is the employees at some service office of Bengkulu City. Sample used in this study was 143 respondents using random sampling technique. Data analysis technique using multiple regression analysis with moderate variable and using SPSS 17.0 sofware. Research design using survey descriptive, the method in this study using Pearson Correlation to test the validity of the data and using Cronbach's alpha to test the reliability of the data. The results of this research shows that the job involvement partially have positive and signifikan effect on employees performance, and organizational commitment was partial mediated the effect of job involvement on employees performance at some service office of Bengkulu city.
\end{abstract}

Keywords : Job involvement, organizational commitment, employees performance

\section{PENDAHULUAN}

Setiap organisasi atau instansi dalam melaksanakan program selalu diarahkan untuk mencapai tujuannya. Salah satu faktor yang menjadi kriteria untuk mencapai kelancaran tujuan suatu organisasi atau instansi adalah mengidentifikasi dan mengukur kinerja pegawainya. Organisasi merupakan suatu kesatuan kompleks yang berusaha mengalokasikan sumber daya manusia secara penuh demi tercapainya suatu tujuan. Apabila suatu organisasi mampu mencapai tujuan yang telah ditetapkan, maka dapat dikatakan bahwa organisasi tersebut efektif. Seiring dengan perkembangannya, semua organisasi dituntut untuk dapat bersaing memberikan pelayanan yang maksimal, tidak terkecuali organisasi pemerintah. Demikian halnya dengan aparat pemerintah sebagai abdi masyarakat dan abdi pemerintah,dituntut untuk dapat memberikan 
pelayanan yang terbaik kepada masyarakat karena hal tersebut sudah merupakan salah satu fungsi yang harus dijalankan oleh pemerintah yang mempunyai tugas menyelenggarakan seluruh proses pelaksanaan pembangunan dalam berbagai sektor kehidupan mulai dari tingkat pusat hingga tingkat daerah.

Tercapainya tujuan organisasi sangat ditentukan dari kinerja dan keefektifan para pegawai dalam menjalankan tugas. Setiap organisasi pada umumnya mengharapkan para pegawainya mampu melaksanakan tugasnya dengan efektif, efisien, produktif dan profesional. Semua ini bertujuan agar organisasi memiliki sumber daya manusia yang berkualitas dan sekaligus memiliki daya saing yang tinggi, sehingga nantinya akan menghasilkan kualitas pelayanan masyarakat yang sesuai dengan harapan masyarakat. Sumber daya organisasi secara garis besar dapat dibedakan kedalam dua kelompok yaitu sumber daya manusia (human resources) dan sumber daya non-sumber daya (misalnya seperti modal dan mesin). Kedua kategori sumber daya tersebut sama-sama pentingnya, akan tetapi sumber daya manusia (SDM) merupakan faktor dominan, karena satu-satunya sumber daya yang memiliki akal, perasaan, keinginan, karsa, pengetahuan dan keterampilan, motivasi, karya dan prestasi. Apabila karyawan memiliki kinerja yang tinggi maka kelangsungan organisasi tersebut akan berjalan dengan baik, sebaliknya apabila kinerja rendah maka laju organisasi akan terbengkalai.

Penelitian ini dilakukan guna menguji teori-teori sebelumnya yang menyatakan bahwa tingkat keterlibatan kerja karyawan dapat menjadi faktor yang mempengaruhi kinerja karyawan (Hackett et al. ; 2001), namun penelitian lain yang dilakukan oleh Rotenberry dan Moberg (2007) mengatakan bahwa pengaruhnya lemah karena itu komitmen organisasi dijadikan mediasi dalam pengaruh hubungan kedua variabel ini sehingga mungkin akan memperkuat pengaruhnya sebagai praduga pertama, sehingga dapat memperbaiki kinerja karyawan.

Berdasarkan uraian tersebut, yang mendorong penulis untuk melakukan penelitian mengenai keterlibatan kerja dan kinerja karyawan, serta bagaimana peranan komitmen organisasi dalam memediasi pengaruh hubungan dari variabel-variabel terkait.

\section{KAJIAN PUSTAKA}

\section{Pengertian Kinerja Pegawai}

Kinerja berasal dari kata job performance atau actual performance yang berarti prestasi kerja atau prestasi sesungguhnya yang dicapai oleh seseorang. Foster dan Seeker (2001) menyatakan kinerja adalah hasil yang dicapai seseorang menurut ukuran yang berlaku untuk pekerjaan yang bersangkutan. Ruky (2002) memberikan pengertian kinerja sebagai berikut performance is defined as the record of outcomes produced on a specified job 
function or activity during time period, atau kinerja adalah catatan tentang hasil-hasil yang diperoleh dari fungsi-fungsi pekerjaan tertentu atau kegiatan selama kurun waktu tertentu. Menurut Keban (2004:192) mendefinisikan kinerja sebagai the record of outcomes produced on a specified job function or activity during a specified time period, dalam definisi ini aspek yang ditekankan adalah catatan tentang outcome atau hasil akhir yang diperoleh setelah suatu pekerjaan atau aktivitas dijalankan selama kurun waktu tertentu.

Kesimpulan dari beberapa teori-teori tentang kinerja tersebut, yaitu kinerja dapat didefinisikan sebagai perilaku-perilaku atau tindakan-tindakan yang mencerminkan tingkat keberhasilan seseorang dalam pekerjaannya selama periode tertentu yang berhubungan dengan tujuan organisasi.

\section{Penilaian Kinerja}

Penilaian kinerja menurut Mondy dan Noe (1993:394) merupakan suatu sistem formal yang secara berkala digunakan untuk mengevaluasi kinerja individu dalam menjalankan tugas-tugasnya. Untuk mengetahui bagaimana perkembangan organisasinya, setiap organisasi harus melakukan penilain kinerja. Sedangkan Mejia, dkk (2004:222-223) mengungkapkan bahwa penilaian kinerja merupakan suatu proses yang terdiri dari :

1. Identifikasi, yaitu menentukan faktor-faktor kinerja yang berpengaruh terhadap kesuksesan suatu organisasi. Hal ini dapat dilakukan dengan mengacu pada hasil analisa jabatan.

2. Pengukuran, merupakan inti dari proses sistem penilaian kinerja. Pada proses ini, pihak manajemen menentukan kinerja pegawai yang bagaimana yang termasuk baik dan buruk. Manajemen dalam suatu organisasi harus melakukan perbandingan dengan nilai-nilai standar atau memperbandingkan kinerja antar pegawai yang memiliki kesamaan tugas.

3. Manajemen, proses ini merupakan tindak lanjut dari hasil penilaian kinerja. Pihak manajemen harus berorientasi ke masa depan untuk meningkatkan potensi pegawai di organisasi yang bersangkutan. Hal ini dapat dilakukan dengan pemberian umpan balik dan pembinaan untuk meningkatkan kinerja pegawainya.

\section{Dimensi Kinerja}

Dimensi kinerja (performance Indicator) digunanakan secara bergantian dengan pengukuran kinerja (performance measures). Indikator yang menjadi bagian dari dimensi kinerja dipakai untuk aktivitas yang dapat ditetapkan secara lebih kualitatif atas dasar prilaku yang diamati (Wibowo, 2010). Menurut Mathis dan Jackson (2002:82) dimensi kinerja yaitu :

1) Kualitas kerja, menyediakan produk dan layanan yang berkualitas merupakan suatu tuntutan bagi perusahaan agar perusahaan dapat bertahan hidup dalam berbagai bentuk persaingan. Hasil kerja yang ideal juga menggambarkan kualitas pengelola produk dan layanan dalam organisasi tersebut. 
2) Kuantitas kerja, perusahaan yang dapat memenuhi target yang telah ditetapkan menunjukkan kemampuan perusahaan tersebut dalam mengelola sumber daya yang dimiliki dalam mencapai tujuannya.

3) Kehadiran, rasa tanggung jawab karyawan pada pekerjaannya dengan tidak selalu meninggalkan pekerjaan sehingga pekerjaan terselesaikan tepat waktu.

4) Pengetahuan, merupakan informasi atau maklumat yang dipahami oleh individu. Dalam hal ini pengetahuan yang dimaksud ialah seberapa paham individu akan tugas yang diberikan, dan apakah individu memilki keterampilan dibidang tersebut.

5) Keandalan, individu menjalankan fungsinya sebagai pegawai dengan baik dan tanpa kesalahan.

6) Kerja sama dengan rekan kerja, kerja sama merupakan tuntutan bagi keberhasilan perusahaan dalam mencapai tujuan yang ditetapkan, sebab dengan adanya kerja sama yang baik akan memberikan kepercayaan (trust) pada berbagai pihak yang berkepentingan, baik secara langsung maupun tidak langsung dengan perusahaan.

\section{Keterlibatan Kerja}

Keterlibatan kerja yaitu dimana seorang karyawan dikatakan terlibat dalam pekerjaannya apabila karyawan tersebut dapat mengidentifikasikan diri secara psikologis dengan pekerjaannya, dan menganggap kinerjanya penting untuk dirinya. Menurut Davis dan Newstrom (1994) keterlibatan kerja adalah keterlibatan mental dan emosional orang-orang dalam situasi kelompok yang mendorong mereka untuk memberikan kontribusi kepada tujuan kelompok dan berbagai tanggung jawab pencapaian tujuan itu. Muchinsky (2000) "job involvement refers to the degree to which a person identifies psychologically with his or her work and the importance of work to one's self-image", pernyataan tersebut menyiratkan bahwa keterlibatan kerja mengacuh pada sejauh mana seseorang mengidentifikasi secara psikologis dengan karyanya dan pentingnya bekerja untuk seseorang dalam citra dirinya. Sedangkan menurut Robbins, (2003:91) mengemukakan karyawan dengan keterlibatan yang tinggi dengan kuat memihak pada jenis kerja yang dilakukan dan benarbenar peduli dengan jenis kerja itu.

\section{Dimensi Keterlibatan Kerja}

Menurut Lodahl dan Kejner (dalam Cohen, 2003), Job Involvement memiliki dua dimensi, yaitu:

\section{A. Performance Self-Esteem Contingency}

Keterlibatan kerja merefleksikan tingkat dimana rasa harga diri seseorang dipengaruhi oleh performansi kerjanya. Aspek ini mencakup tentang seberapa jauh hasil kerja seorang karyawan (performance) dapat mempengaruhi harga dirinya (self-esteem). Harga diri didefinisikan sebagai suatu indikasi dari tingkat dimana individu mempercayai dirinya mampu, cukup, dan berharga (Harris \& Hartman, 2002).

b. Pentingnya Pekerjaan Bagi Gambaran Diri Total Individu 
Dimensi ini merujuk pada tingkat sejauh mana seseorang mengidentifikasikan dirinya secara psikologis pada pekerjaannya atau pentingnya pekerjaan bagi gambaran diri totalnya. (Dubin (dalam Cohen, 2003) mengatakan bahwa orang yang memiliki keterlibatan kerja (Job Involvement) adalah orang yang menganggap pekerjaan sebagai bagian yang paling penting dalam hidupnya. Ini berarti bahwa dengan bekerja, ia dapat mengekspresikan diri dan menganggap bahwa pekerjaan merupakan aktivitas yang menjadi pusat kehidupannya. Karyawan yang memiliki tingkat keterlibatan yang tinggi sangat memihak dan benar-benar peduli dengan bidang pekerjaan yang mereka lakukan (Robbins, 2009:303).

\section{Komitmen Organisasi}

Menurut Meyer dan Allen (1991) komitmen dapat juga berarti penerimaan yang kuat individu terhadap tujuan dan nilai-nilai organisasi, dan individu berupaya serta berkarya dan memiliki hasrat yang kuat untuk tetap bertahan di organisasi tersebut. Secara khusus, Meyer et al. (1993) mengemukakan bahwa pegawai yang memiliki affective commitment yang tinggi tetap tinggal karena pegawai menginginkannya. Pegawai yang memiliki normative commitment atau moral tetap tinggal karena pegawai merasa seharusnya melakukannya demikian, dan mereka yang memiliki continuance commitment yang tinggi tetap tinggal karena pegawai merasa memerlukannya, namun berdasarkan beberapa penelitian continuance commitment tidak memiliki hubungan yang sangat erat dengan seberapa sering seorang anggota tidak hadir atau absen dalam organisasi dan juga semakin besar continuance commitment seseorang, maka ia akan semakin bersikap pasif atau membiarkan saja keadaan yang tidak berjalan dengan baik (Allen dan Meyer;1993).

\section{Dimensi Komitmen Organisasi}

Menurut Luthans (2006) komitmen organisasi memiliki tiga dimensi yaitu:

a. Dimensi Komitmen Afektif

Komitmen afektif adalah keterikatan emosional karyawan, identifikasi, dan keterlibatan dalam organisasi. Pada dimensi ini karyawan memilih organisasi disebabkan oleh adanya dedikasi yang tinggi agar perusahaan menjadi berkembang.

b. Dimensi Komitmen Normatif, adanya perasaaan wajib untuk tetap berada dalam organisasi karena memang harus begitu; tindakan tersebut merupakan hal benar yang harus dilakukan. Hecket et al. mengatakan komitmen normatif merupakan perasaan loyailty terhadap organisasi tertentu.

c. Dimensi Komitmen Kontinyu, omitmen kontinyu adalah komitmen berdasarkan kerugian yang berhubungan dengan keluarnya karyawan dari organisasi 


\section{METODE PENELITIAN}

\section{Jenis Penelitian}

Berdasarkan masalah yang diteliti, jenis penelitian ini merupakan penelitian deskriptif, dengan pendekatan kuantitatif. Penelitian deskriptif dipakai untuk menggambarkan, menjelaskan, dan menguraikan variabel-variabel terkait dalam penelitian. Penelitian ini mencoba menjelaskan pengaruh keterlibatan kerja terhadap kinerja dengan komitmen organisasi sebagai variabel mediasi (Intervening).

\section{Metode Pengumpulan Data}

Pengumpulan data pada penelitian ini bersumber dari data primer. Menurut Sekaran (2006: 60-61) pengumpulan data dalam penelitian dapat dilakukan menggunakan dua jenis sumber data sekaligus, yaitu sumber data primer dan data skunder

\section{Metode Pengumpulan Sampel \\ Populasi}

Indriantoro mendefinisikan populasi merupakan sekelompok orang, kejadianatau segala sesuatu yang mempunyai karakteristik tertentu (2002: 115). Populasi dalam penelitian ini yaitu seluruh pegawai diseluruh Kantor Dinas dalam wilayah tugas di Kota Bengkulu.

\section{Sampel}

Indriantoro mendefinisikan sampel adalah sebagian dari populasi, atau dalam sebuah penelitian yang diteliti hanya sebagian dari elemen-elemen populasi (2002: 115). Teknik sampling yangdigunakan pada penelitian ini yaitu probability sampling,

\section{Uji Validitas dan Reliabilitas Uji Validitas}

Uji validitas dilakukan untuk memastikan seberapa baik suatu instrumen digunakan untuk mengukur konsep yang seharusnya diukur. Azwar (2000) validitas merupakan sejauh mana ketepatan dan kecermatan suatu alat ukur dalam melakukan fungsinya.

\section{Uji Reliabilitas}

Suharto (2009) menyatakan Reliabilitas adalah serangkaian pengukuran atau serangkaian alat ukur yang memiliki konsistensi bila pengukuran yang dilakukan dengan alat tersebut dilakukan secara berulang. Reliabilitas berkenaan dengan tingkat keajegan atau ketetapan hasil pengukuran (Nana Syaodih Sukmadinata, 2009).

\section{Teknik analisis data}

Teknik analisis data merupakan teknik yang digunakan dalam proses pengujian data yang hasilnya digunakan sebagai bukti yang memadai untuk menarik kesimpulan penelitian. Dalam penelitian ini teknik analisis data 
yang digunakan yaitu regresi linier berganda dengan menggunakan variable mediasi.

\section{Uji Hipotesis}

Uji hipotesis pada penelitian ini menggunakan Uji statistik f pada dasarnya menunjukkan apakah semua variabel independen yang dimasukkan dalam model mempunyai pengaruh secara bersamasama dengan variabel dependen dan Uji t pada dasarnya menunjukkan seberapa jauh pengaruh satu variabel independen secara individual menerangkan variasi variabel dependen.

\section{HASIL PENELITIAN DAN PEMBAHASAN}

Berdasarkan hasil analisis yang dilakukan memperlihatkan bahwa ada pengaruh yang signifikan dan positif antara keterlibatan kerja terhadap kinerja pegawai dengan dimediasi komitmen organisasi. Sehingga semakin baik atau tinggi variabel keterlibatan kerja maka akan semakin meningkat juga variabel kinerja pegawai dan semakin baik variabel komitmen organisasi maka mediasi yang dapat memperkuat akan terbentuk.

Keterlibatan kerja merupakan salah satu variabel yang berpengaruh sigfikan terhadap komitmen organisasi. Dalam penelitian ini dapat ditunjukkan dengan nilai $\beta$ sebesar 0,853, t-hitung sebesar 19.310 dengan signifikansi $0,000(\rho<0,005)$ yang memberi pemahaman bahwa setiap penambahan satu satuan atau satu tingkatan keterlibatan kerja akan berdampak pada meningkatnya komitmen organisasi sebesar 0.853. Dalam hal ini keterlibatan kerja yang tinggi menyebabkan individu lebih berkomitmen terhadap organisasinya, sebaliknya keterlibatan kerja yang rendah akan menjadikan individu kurang berkomitmen terhadap organisasinya. Hal ini dikarenakan keterlibatan kerja merupakan variabel yang penting dalam kehidupan banyak orang (Blau dan Bloal, 1987). Keterlibatan kerja yang tinggi berperan dalam membentuk performance kerja, kualitas, dan kuantitas hasil kerja yang lebih besar serta efisiensi kerja yang tinggi (Uygur dan Killic, 2009).

Bedasarkan hasil penelitian yang sudah dilakukan bahwa terlihat adanya pengaruh yang positif dan signifikan dari variabel keterlibatan kerja terhadap kinerja pegawai pada beberapa Kantor dinas di Kota Bengkulu. Hal ini memberikan kesimpulan bahwa keterlibatan kerja yang tinggi maka kinerja pegawainya juga akan lebih baik untuk menunjang pekerjaan mereka sebagai seorang pegawai, seperti halnya kemampuan mereka dalam berpikir untuk memahami keadaan, dan menjalankan tugas mereka dengan penuh tanggung jawab sesuai dengan standar oprasi dan tenggat waktu yang ada. Serta mereka bisa menerapkan pengetahun dan keahlian mereka sesuai dengan kebutuhan sebagai seorang pegawai. 
Penelitian ini juga menunjukan bahwa komitmen organisasi berpengaruh terhadap kinerja pegawai dengan pengaruh sebesar 72,4\%, seperti halnya yang dikemukakan oleh Streers (1991) bahwa karyawan yang berkomitmen rendah akan berdampak pada turnover tingginya absensi, meningkatnya kelambatan kerja dan kurangnya intensitas untuk bertahan sebagai karyawan di organisasi tersebut, rendahnya kualitas kerja dan kurangnya loyalitas pada perusahaan. Ada pengaruh komitmen afektif hasil organisasi seperti kinerja dan perputaran karyawan bila dibandingkan dengan dua dimensi komitmen lain (Robbins, 2008). Penelitian yang dilakukan oleh Suswati dan Budianto mengatakan adapun secara parsial komitmen afektif mempunyai pengaruh positif dan signifikan terhadap kinerja. Kemudian menurut hasil riset Frederick Reichheld (1993), dalam the loyalty Effect, menunjukkan bahwa ada korelasi positif antara komitmen karyawan dengan tingkat kinerja perusahaan. Dari ketiga jenis komitmen, komitmen afektif adalah yang paling diinginkan oleh perusahaan. Karyawan yang memiliki komitmen afektif akan cenderung tetap tinggal (bekerja dalam perusahaan), mereka akan merekomendasikan kepada orang lain bahwa perubahan tempat bekerjanya merupakan tempat yang bagus untuk bekerja, mereka akan suka melakukan kerja tambahan untuk perusahaan, mereka akan mau memberikan saran-saran bagi perbaikan dan kemajuan perusahaan (Fuad Mas'ud ,2002).

\section{KESIMPULAN}

\section{Kesimpulan}

Berdasarkan hasil penelitian dan pembahasan yang telah dikaji secara empiris tentang keterlibatan kerja, komitmen organisasi, dan kinerja pegawai maka kesimpulan dari penelitian ini adalah :

1. Keterlibatan kerja sigifikan mempengaruhi komitmen organisasi hal ini menunjukan bahwa memang terdapat korelasi pada keduanya.

2. Keterlibatan kerja dinyatakan bisa mempengaruhi secara langsung kinerja pegawai pada beberapa Kantor dinas di Kota Bengkulu.

3. Komitmen organisasi juga signifikan mempengaruhi kinerja pegawai. 4. Pada penenlitian ini komitmen organisasi menjadi variabel mediasi bagi pengaruh keterlibatan kerja terhadap kinerja pegawai namun hanya secara parsial, karena nilai dari pengaruh langsung lebih besar daripada pengaruh tidak langsung.

\section{Saran}

Berdasarkan kesimpulan yang telah dijelaskan diketahui bahwa adanya pengaruh yang positif dan signifikan diantara variabel keterlibatan kerja, komitmen organisasi, dan kinerja pegawai. Maka peneliti memberikan saran yang perlu dipertimbangkan sehingga kedepannya Kantor Dinas di Kota 
Bengkulu semakin baik nantinya. Saran-saran yang dapat menjadi pertimbangan pihak Kantor Dinas adalah sebagai berikut :

1. Pegawai Dinas Kota Bengkulu harus terus menjadi individu yang mencintai pekerjaan mereka sehingga mereka akan menghargai pekerjaan mereka. Sehingga terlihat adanya indikasi positif yang terjadi ketika keterlibatan kerja seseorang tinggi maka kinerja individu tersebut akan baik, karena dengan terlibat pada pekerjaannya individu tersebut akan melakukan yang terbaik bagi pekerjaan.

2. Pegawai di Kantor Dinas Kota Bengkulu harus terus menjaga komitmen mereka pada organisasi karena dengan komitmen organisasi yang tinggi maka pegawai akan merasa bangga pada organisasi mereka dan berusaha melakukan yang terbaik untuk organisasi. Melakukan yang terbaik bagi organisasi tersebut akan dimulai dari menghargai pekerjaan mereka dan hal ini akan membuat mereka melakukan yang terbaik untuk hasil pekerjaan mereka, hal inilah yang akan menunjukan bahwa kinerja pegawai maupun organisasi baik.

3. Penelitian yang dilakukan ini hanya menggunakan 143 responden dalam lingkup pegawai dari tiga Kantor Dinas di Kota Bengkulu. Untuk peneliti yang ingin melakukan penelitian yang sama untuk kedepannya ada baiknya menambahh jumlah responden dan ruang lingkup dan generalisasi penelitian menjadi

semakin luas sehingga hasil penelitian yang diperoleh lebih komprehensif dan memperoleh respresentatif sesuai dengan apa yang hendak diukur dalam penelitian serta untuk menambah variabel yang terkait dengan kompetensi yang tidak diteliti dalam penelitian ini seperti : gaya kepemimpinan, budaya organisasi, dan kepuasan kerja.

\section{DAFTAR PUSTAKA}

Aamir, Ali dan Chughtai. 2008. Impact of Job Involvement on In-Role Job Performance and Organisational Citizenship Behaviour. Journal of Human Resource Management.

Ahmad S Ruky. 2002. Sistem Manajemen Kinerja. PT Gramedia Pustaka Utama : Bandung.

Allen, N., dan Meyer, P. 1990. The measurements and antacedents of affective, continuance and normative commitmen. Journal of Accupational Psychology, 63: 1-18.

Arikunto, S, 2006. Prosedur Penelitian Suatu Pendekatan Praktik. Ed Revisi VI. PT Rineka Cipta, Jakarta.

Baron, R. M., dan Kenny, D. A. 1986. The moderator-mediator variable distinction in social phychological research. Journal of Applied psychology, 51: (6). 
Becker BE, Mark A, dan D. Ulrich. 2001. HR Scorecard; Mengaitkan Manusia, Strategi dan Kinerja. Erlangga : Jakarta.

Chen, Z.X., Tsui, A.S., dan Farh, J.L. 2002. Loyalty to supervisor vs organisational commitment: Relationships to employee performance in China. Journal of Occupational and Organisational Psychology, (75), 339356.

Chunghtai, A., Ali. 2008. Impact of Job Involvement on In-Role Job Performance and Organizational Citizenship Behavior. Institude of Behavior and Applied Management: 69-183.

David, Mc. Clelland. 1997. Managemen Sumber Daya Manusia. Prenhallindo: Jakarta.

Davis, Keith dan John W. Newstorm. 1994 Perilaku Dalam Organisasi, Alih Bahasa Agus. Dharma, Erlangga: Jakarta.

Dessler, Gary. 2006. Manajemen Sumber Daya Manusia, Jilid II. Insdeks: Jakarta.

Dessler, Gary. 2009. Manajemen Sumber Daya Manusi, Jilid II. PT Indeks halaman 46. Jakarta: Edisi Kesepuluh.

Diefendorf, J., Brown, D., Kamin A., dan Lord. 2002. Examining the roles of job involvement and work centrality in predicting organisational citizenship behaviours and job performance. Journal of Organisational Behaviour, (23), 93-108.

Foster, Bill. 2001. Pembinaan untuk Peningkatan Kinerja Karyawan. PPM: Jakarta.

Gomes, Faustino Cardoso. 2003, Manajemen Sumber Daya Manusia. Penerbit Andi : Yogyakarta.

Greenleaf, R. K. (2002). Servant Leadership A Journey Into The Nature of Legitimate Power \& Greatness. 25th Anniversary Edition. Paulist Press; Marwah New Jersey.

Hackett, R. D., Bycio, P., dan Hausdorf, P. A. 1994. Further Assasement of Allen Meyer (1991) three component of organizational commitment. Journal of Applied psychology, 79: (1): 15-23.

Hackett, R.D., Lapierre, L.M, dan Hausdorf. 2001. Understanding the links between work commitment constructs. Journal of Vocational Behaviour, (58), 392-413.

Indrianto, N dan B. Supomo, 2002, Metodelogi Penelitian Bisnis, Yogyakarta, BPFE- Yogyakarta.

Indriantoro, Nur, Supomo, Bambang. 2002. Metodologi penelitian bisnis untuk akuntansi dan manajemen.Yogyakarta : BPFE-Yogyakarta.

Islam, T., et al. 2012. Does Organisational commitment enhance the relationship between job involvement and in-role job performance. Journal of Human Resource Management.

Judd, C.M., dan Kenny, D.A. 1981. Process Analysis: Estimating mediation in treatment evaluations. Evolution Review, 5: 602-619.

Kartaningsih, S.H. 2007. Analisis Pengaruh Budaya Organisasi dan Keterlibatan Karyawan. Tesis. (tidak diterbitkan). Semarang: Universitas Diponegoro Semarang. 
Keban, Yeremias T. 2004. Enam Dimensi Strategis Administrasi Publik Konsep,Teori dan Isu. Gava Media: Yogyakarta.

Luthans, Fred, 2005. Perilaku Organisasi, Edisi Sepuluh. Diterjemahkan oleh : Vivin Andhika Yuwono; Shekar Purwanti; Th.Arie Prabawati; dan Winong Rosari. Andi: Yogyakarta.

Luthans, Fred. 2006. Perilaku organisasi. Andi: Yogyakarta.

Mahfuz, Judeh. 2011. An Examination of the Effect of Employee Involvement on Teamwork Effectiveness: An Empirical Study. International Journal of Business and Management.

Mangkunegara, Anwar, Prabu. 2002. Manajemen Sumber Daya Manusia. Remaja Rosdakarya: Bandung.

Mathis, R. L \& Jackson, J. H. (2001). Manajemen Sumber Daya Manusia. Ninth Edition. Penerjemah oleh Jimmy Sadeli dan Bayu Prawira Hie. Salemba : Jakarta.

Mathis, Robert L. dan Jackson, John H. 2006. Human Resources Management. Edisi ke 10 , Salemba Empat: Jakarta.

Mathis, Robert, L dan Jackson, John, H. 2002. Human Resource Managemen., alih bahasa. Salemba Empat: Jakarta.

Moeheriono, Prof, Msi, 2009. Pengukuran Kinerja Berbasis Kompetensi Ghalia: Bogor.

Mohsan, F., Nawaz, M.M., Khan, M.S., Shaukat, Z., Islam, T., Aslam, N. 2011. Impact of job involvement on organizational citizenship behavior (OCB) and in-role job performance. European Journal of Social Sciences, (24), 494-502.

Mondy, Noe. 1993. Human Resource Management. Division Of Simon \& Schuters: United State Of America.

Mowday, R.T., Porter, L.W., \& Steers, R.M. 1982. Employee-organization linkages: The psychology of commitment, absenteeism, and turnover. Academic Press : New York.

Pareke, F. Js. 2004. Hubungan Keadilan dan Kepuasan Dengan Keinginan Berpindah: Peran Komitmen Organisasional Sebagai Variabel Pemediasi. Jurnal Siasat Bisnin, 9: (2) 157-177.

Paul F, Rotenberry dan Philip J. Moberg. 2007. Assesing the Impact of Job Involvement on Performance. Management Research News, (30), 203215.

Prasetyo, Dwi. 2011. Pengaruh motivasi, kompetensi dan komitmen organisasi terhadap kinerja karyawan PT Asuransi Jiwa Sraya Tbk. Jurnal Manajemen. Universitas Pembangunan Nasional "veteran".

Robbins, Stephen P. 2002. Prinsip-prinsip Perilaku Organisasi. PT. Erlangga: Jakarta.

Safaria, Siti. 2013. Pengaruh keterlibatan kerja terhadap kinerja karyawan pada PT Seascape Suveys. Jurnal Manajemen dan Bisnis.

Sari, D.A. 2010.Uji Validitas Alat ukur Big Personality (adaptasi dari IPIP) Pada Mahasisiwa Universitas Islam Negeri Syarif Hidayatullah. Skripsi tidak diterbitkan. Jakarta ; Fakultas Psikologi Universitas Islam Negeri Syarif Hidayatullah.

Sekaran, Uma. 2006. Research Methods For Business. Salemba Empat : Jakarta. 
Setiani, Ari. 2011. Pengaruh keterlibatan kerja dan komitmen organisasi terhadap kinerja wartawan umum harian suara merdeka. Semarang; Program Sarjana Universitas Negeri Semarang.

Umam, Khaerul, 2010. Perilaku Organisasi. Pustaka Setia: Bandung.

Van Dyne, L., Graham, J. W., dan Dienesch, R. M. 1994. Organizational Citizenship Behavior: Construct Redefinition, Measurement, and Validation. Academy of Management Journal, 37 (4): 765-802.

Wibowo, 2010. Manajemen Kinerja, Edisi Ketiga. Rajawali Pers: Jakarta 